\title{
JUURNAL.RU
}

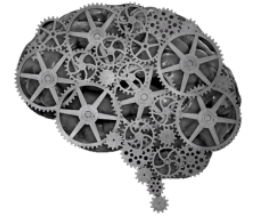

COMPANY GROUP "INTELLEKT"

Киселева Е.В. ГБПОУ Самарской области «Самарский соииально-педагогический колледж» Самара, Россия

doi: 10.18411/lj2016-5-3-07

\section{Влияние занятий плаванием, проводимых в форме творческой игры на развитие дыхательной системы дошкольника}

Для обучения детей дошкольного возраста плаванию разработаны и обоснованы различные методики проведения занятий (Осокина Т.И., 1991; Меньшуткина Т.Г., 1999; Булгакова Н.Ж., 2001; Еремеева Л.Ф., 2005; Петрова Н.Л., Баранов В.А., 2006). Исследованием формирования навыка плавания у детей дошкольного возраста путем включения в программу занятий различных элементов игры занимались В.В. Дукальский, Е.Г. Маряничева (1990); Н.Г. Пищикова (2008) и др.

Вместе с тем, известная практика обучения детей плаванию показала, что эффект использования этих методик связан также с возникающими трудностями психологического плана. Так по данным В.Я. Лопухина(1995) и Е.А. Мухиной(1999) только 15\% детей в возрасте 5-6 лет испытывали удовольствие и радость на первых занятиях обучения плаванию, а у 10-12\% занимающихся контакт с водой вызывал вообще отрицательную психическую реакцию.Отсутствие чувства уверенности и комфорта в водной среде отрицательновлияло на время и эффективность проведения начальных этапов обучения плаванию дошкольников.

Начиная с середины XX века, в обучении плаванию стало уделяться большое внимание игровому методу и на сегодняшний момент существует большое количество игр в воде (более 200 игр по разным источникам). Однако 
существует потребность в таких играх, которые будут легко проводиться в воде, легко регулировать нагрузку и, в то же время, интересны, понятны и известны детям дошкольного возраста. Использование творческих игр может быть эффективным средством в начальном обучении плаванию. Выполнение детьми привлекательных ролей на занятиях в воде, требующих систематически возрастающих познавательных и физических усилий, с учётом дифференцированных и индивидуальных возможностей детей будет способствовать более эффективному развитию двигательных, плавательных и функциональных способностей.

Мы решили проверить влияние использования творческих игр в занятиях плаванием с детьми 5-6 лет на работу дыхательной системы дошкольника.

В план исследовательской деятельности вошли:

- диагностика работы дыхательной системы старших дошкольников во время плавания;

- отбор игр, подходящих для обучения плаванию старших дошкольников;

- проведение занятий плаванием с использованием игр в воде: подвижных, творческих, театрализованных, сюжетно-ролевых;

- контроль изменений работы дыхательной системы старших дошкольников во время плавания.

Диагностика работы дыхательной системы старших дошкольников во время занятия плаванием проводилась по методике М.Д.Маханевой: определялась продолжительность задержки дыхания в позе «поплавок».

Детям предлагалось набрать воздух, задержать дыхание и опуститься под воду в позе «поплавка». При помощи секундомера фиксировалось время, которое ребенок проводит под водой. Результаты подсчитывались. Каждому значению было присвоено определенное количество балов: 1 балл = 1 секунде. Высокий уровень - 25 с и более, средний уровень - до 23 с, низкий уровень - 
менее 20с.Результаты обследования детей старшего дошкольного возраста отражены в Таблице 1.

Таблица 1

Результаты обследования продолжительности задержки дыхания детей старшей группыМБДОУ № 460 г. Самары.

\begin{tabular}{|c|c|c|c|c|}
\hline \multirow[b]{2}{*}{$\begin{array}{l}\text { № } \\
\Pi \backslash \Pi\end{array}$} & \multirow[b]{2}{*}{$\begin{array}{l}\text { Имена } \\
\text { детей }\end{array}$} & \multicolumn{3}{|c|}{ Задержка дыхания (поза «поплавок»). } \\
\hline & & $\begin{array}{l}\text { Низкий уровень } \\
\text { (менее 20c) }\end{array}$ & $\begin{array}{c}\text { Средний уровень } \\
\text { (до } 23 \text { с) }\end{array}$ & $\begin{array}{c}\text { Высокий уровень } \\
\text { (25с и более) }\end{array}$ \\
\hline 1. & Милана А. & $18 \mathrm{c}$ & & \\
\hline 2. & Тимофей Т. & & $20 \mathrm{c}$ & \\
\hline 3. & Арина П. & & $21 \mathrm{c}$ & \\
\hline 4. & Надя $\Phi$. & & $20 \mathrm{c}$ & \\
\hline 5. & Настя И. & $14 \mathrm{c}$ & & \\
\hline 6. & Арсений П. & $15 \mathrm{c}$ & & \\
\hline 7. & Каролина С. & & $21 \mathrm{c}$ & \\
\hline 8. & Сергей П. & & & $28 \mathrm{c}$ \\
\hline 9. & Катя C. & & $21 \mathrm{c}$ & \\
\hline 10. & Полина Ш. & $11 \mathrm{c}$ & & \\
\hline \multicolumn{2}{|c|}{$\begin{array}{l}\text { Общий } \\
(10)\end{array}$} & 4 & 5 & 1 \\
\hline
\end{tabular}

Мы решили повторить методику Герасимовой Ю.В. и провести обучение плаванию в сочетании с театрализованной игрой.

Для повышения функциональности работы дыханияна утренней гимнастике проводились подготовительные упражнения на развитие дыхания и укрепления всех групп мышц: «Покажем и спрячемся», «Жучок на спине», «Ветер», «Насос», «Остуди чай», «Пускаем мыльные пузыри»и другие.

В процессе выбора игр, мы заметили, что при большом количестве игр в воде: простейших (без сюжета), командных, нет игр по обучению плаванию, которые можно было бы использовать на протяжении всего занятия, что эмоционально объединило бы детей. Основой содержания занятий стало проведение сюжетно-ролевых игр в воде (по методике Герасимовой Ю.В.). Было отобрано 5 сказок, каждая сказка изучалась на 4 занятиях. Во время занятий в воде, использовались следующие сказки (по методике Герасимовой Ю.В.), которые распределялись по возрастающей сложности: 
- сюжет сказки «Колобок» был использован для выполнения контрастных упражнения по освоению с водой;

- сказка «Репка» - для выполнения упражнений на дыхание;

- «Три поросенка» - для выполнения (упражнений на погружение);

- «Гуси лебеди» - для выполненияупражнений на всплывание.

После 16 занятий, с учетом двухразового посещения бассейна в неделю и продолжительностью каждого занятия 30 минут, в мелком бассейне (глубина воды 0,7 - 0,9 м) был проведён контроль работы дыхательной системы детей, участвующих в исследовании. Контроль промежуточных результатов проводился на занятии по плаванию построенного по сюжету сказки «Три поросёнка». Эти результаты отражены в Таблице 2.

Таблица 2

Результаты продолжительности задержки дыхания у детей старшей группьво время театрализованной игры «Три поросёнка» МБДОУ № 460 г.

Cамары.

\begin{tabular}{|c|c|c|c|c|}
\hline \multirow{2}{*}{$\begin{array}{c}\text { № } \\
\Pi \backslash \\
\Pi\end{array}$} & \multirow{2}{*}{$\begin{array}{l}\text { Имена } \\
\text { детей }\end{array}$} & \multicolumn{3}{|c|}{ Уровень выполнения задержки дыхания в позе «поплавок». } \\
\hline & & $\begin{array}{l}\text { Низкий -менее } \\
20 \mathrm{c.}\end{array}$ & Средний -до 23 с. & $\begin{array}{c}\text { Высокий - 25c. и } \\
\text { более }\end{array}$ \\
\hline 1. & Милана А. & & 20сек & \\
\hline 2. & Тимофей Т. & & & 25 сек \\
\hline 3. & Арина П. & & 22 сек & \\
\hline 4. & Надя $\Phi$. & & 22 сек & \\
\hline 5. & Настя И. & & 21 сек & \\
\hline 6. & Арсений П. & & 22 сек & \\
\hline 7. & $\begin{array}{l}\text { Каролина } \\
\text { С. }\end{array}$ & & 22 сек & \\
\hline 8. & Сергей П. & & & 32 сек \\
\hline 9. & Катя C. & & 22 сек & \\
\hline 10. & Полина Ш. & 19 сек & & \\
\hline Bce & о 10 детей & 1 & 7 & 2 \\
\hline
\end{tabular}

В данном случае снизилось количество детей с низким уровнем и повысилось со средним и высоким. Сравнивая результаты промежуточных результатов с данными диагностики, мы получили Таблицу 3. 
Сравнительные результаты, развития продолжительности задержки дыханиядетей старшей группыМБДОУ № 460 во время творческой игры и в тренировочном упражнении на занятии плаванием.

\begin{tabular}{|c|c|c|c|c|c|}
\hline № & Этапы эксперимента & $\begin{array}{l}\text { К-во детей, } \\
\text { участвующи }\end{array}$ & $\begin{array}{r}\text { К-во де } \\
\text { дыхаг }\end{array}$ & $\begin{array}{l}\text { по уровню } \\
\text { в позе «по }\end{array}$ & $\begin{array}{l}\text { держки } \\
\text { авок» }\end{array}$ \\
\hline $\begin{array}{l}\Pi \\
\backslash \\
\Pi\end{array}$ & & $\begin{array}{c}\text { х } \\
\text { в } \\
\text { эксперимент } \\
\text { е }\end{array}$ & $\begin{array}{c}\text { Высокий } \\
\text { (25с и } \\
\text { более) }\end{array}$ & $\begin{array}{l}\text { Средний } \\
\text { (до } 23 \text { с) }\end{array}$ & $\begin{array}{c}\text { Низкий } \\
\text { (менее } \\
\text { 20c) }\end{array}$ \\
\hline 1. & $\begin{array}{l}\text { Упражнение } \\
\text { занятии }\end{array}$ & 10 & 1 & 5 & 4 \\
\hline 2. & $\begin{array}{l}\text { Творческая игра в } \\
\text { бассейне-Три } \\
\text { поросёнка }\end{array}$ & 10 & 2 & 7 & 1 \\
\hline
\end{tabular}

Проведённая работа показала, что дети, играя в сказку, вживаются в образ главных героев, пытаясь преодолеть стоящие на их пути препятствия и трудности, погружаясь в мир фантазии и волшебства, забывают страх, и скованность в движениях пропадает.

Частичное включение в занятия по обучению плаванию сюжетов сказки в экспериментальной группе положительно повлияло на качество овладения не только навыками плавания, но и на укрепление дыхательной системы детей.

Наша гипотеза подтвердилась: проведение театрализованных и творческих игр в воде при систематическом проведении занятий плаванием (2 раза в неделю) повысило функцию работы лёгких у детей 5-6 лет.

Таким образом, можно сказать, что использование творческих игр на основе сказочных сюжетов в занятиях плаванием, повышает эффективность процесса работы лёгких у детей 5-6 лет и позволяет лучше решать задачи обучения плаванию, развития и оздоровления, способствует формированию устойчивого интереса к занятиям. 


\section{Литература:}

1. Воронова, Е.К. Программа обучения плаванию в детском саду / - СПб. : ДЕТСТВО-ПРЕСС, 2003. - 80 c.

2. Маханева М.Д., Баранова Г.В. Фигурное плавание в детском саду./ Методическое пособие.-М: ТЦ Сфера, 2009. - 64 с.

3. Пищикова Н.Г. Обучение плаванию детей дошкольного возраста: занятия, игры, праздники / - М.: Изд-во «Скрипторий», 2008. - 88 с. 